\section{Stimulation of Active Transport of Sodium from Sodium-rich Frog Muscle by Insulin and Lactate}

ACTIVE excretion of sodium from muscle was first shown for rat muscle in vivo by Conway and Hingerty ${ }^{1}$, and for isolated frog muscle by Desmedtz and by Conway et al. ${ }^{3}$. The latter workers found that when the sodium-level of muscle fibres was increased to about $60 \mathrm{mM} / 1$. fibre water, by overnight immersion in cold potassium-free Ringer-Conway fluid containing $120 \mathrm{mM} / \mathrm{l}$. sodium, it was necessary to reduce the external sodium in the presence of $10 \mathrm{~m} M /$ l. potassium chloride before active extrusion of sodium would occur.

The concept of a critical energy barrier to extrusion of sodium was introduced by Conway, ${ }^{4,5}$ to explain the necessity of reducing the external sodium, or of increasing the external potassium concentration above its normal level in plasma for excretion of sodium to occur. The energy barrier takes account of the electrical and osmotic gradients against which the sodium is extruded and is expressed by the relation:

$$
\mathrm{d} G / \mathrm{d} n=R T \cdot \ln [\mathrm{Na}]_{0} /[\mathrm{Na}]_{l}+E_{m} F
$$

where $\mathrm{d} G / \mathrm{d} n$ is the free energy change per equivalent of sodium extruded, $E_{\mathrm{m}}$ the mean membrane potential of the muscle fibres (outside minus inside) in the recovery fluid, measured by the micro-electrode technique ${ }^{6}$, and $[\mathrm{Na}]_{0}$ and $[\mathrm{Na}]_{i}$ the sodium concentrations in the recovery fluid and fibres respectively. In previous experiments ${ }^{5}$, it was found that under the conditions used, sodium could not be extruded against a barrier greater than 2,000 cal., but it could be extruded if the barrier was reduced by lowering $\mathrm{Na}_{0}$ or by increasing $\mathrm{K}_{0}$, and thereby reducing $E_{\mathrm{m}}$.

In the presence of 30 units of insulin and $1 \mathrm{mM}$ lactate per litre recovery fluid, I found that with muscles loaded with sodium as deseribed above, the extrusion of sodium would occur, and at the normal plasma potassium-level of $2.5 \mathrm{~m} M /$ l. against an external sodium concentration of $120 \mathrm{mM} / 1$. (see Table 1). At the same time about $30 \mathrm{mM}$ potassium was gained by the muscles. It was found that the energy barrier against which sodium was extruded was 2,500 cal. at time of re-immersion in recovery fluid, rising to about 3,000 cal., after $3 \mathrm{hr}$., as extrusion reached completion. The mean membrane potential was $96 \pm 0.9 \mathrm{mV}$. on re-immersion falling to $90 \pm$ $1.9 \mathrm{mV}$. towards the end. The energy barrier here was closer to that computed for the intact animal ${ }^{5}$, namely, 4,000 cal.

Examining the chloride movement under the conditions of previous experiments ${ }^{5}$, I found that during immersion in potassium-free Ringer fluid the muscles gained an average of $20 \mathrm{mM}$ chloride per litre fibre water, and that this chloride remained in the fibres even when the sodium had been extruded in exchange for potassium. However, addition of insulin and lactate to the recovery fluid produced a marked decrease in the fibre chloride.

The effect of some inhibitors on the extrusion of sodium under these conditions is summarized in Table 1 .

It would appear from these experiments that the fall of the critical energy-level of extrusion of sodium from isolated muscle is related to a fall in the maximum electro-chemical potential at which the sodium pump can excrete sodium ions. In the light of these observations, and those of Manery et al..$^{2,8}$ it seems possible that insulin and lactate may play a part in
Table 1. Frog Sartori Soaked Ovgrnight at $0^{\circ} \mathrm{C}$. In PotassiomFREE RINGER FLUID CONTAINING $120 \mathrm{MM}$ SODIUM, THFN RE-IMMERSED 120 MM SODIUM, 2.5 IM POTASSIUM, 1 MM LACTATH AND 30 UNITS

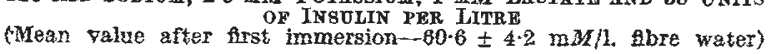
Sodium concentration in muscle ( $\mathrm{mM} / 1$. fibre water)

Inhibitor used Ouabain $\left(10^{-6} M / 1\right.$. $)$ Iodoacetate $(2 \mathrm{mM} / 1$.) $\begin{array}{ll}25 \cdot 4 \pm 1 \cdot 4 & 46 \cdot 1 \pm 1 \cdot 8 \text { (11) } \\ 23 \cdot 2 \pm 2 \cdot 5 & 65 \cdot 8 \pm 3 \cdot 6(14)\end{array}$

Companion muscles were used. No. of experiments shown in brackets.

the extrusion of sodium from frog muscle in vivo. They may also be the active constituents of plasma, which prevent the loss of potassium from isolated frog muscle, and maintain the membrane potential of the muscle at a higher value than found using Ringer fluid as immersion fluid ${ }^{10}$. In this connexion it may be of interest to note that Zierler ${ }^{11}$ has reported that insulin increases the membrane potential of isolated muscle of rat.

My thanks are due to Prof. E. C. Conway for advice and discussion, and to the Medical Research Council of Ireland for grants-in-aid.

RODERICE P. KERNAN

Department of Biochemistry and Pharmacology, University College, Dublin.

${ }^{1}$ Conway, E. J., and Hingerty, D., Biochem. J., 42, 372 (1948).

${ }^{8}$ Desmedt, J. E., J. Physiol., 121, 191 (1953).

${ }^{3}$ Carey, M. J., Conway, E. J., and Keman, R. P., J. Physiol., 148, 51 (1959).

"Conway, E. J., Nature, 187, 394 (1960).

${ }^{5}$ Conway, E. J., Kernan, R. P., and Zadunaisky, J. A., J. Physiol., 155,263 (1961).

- Graham, J., and Gerard, R. W., J.Cell. Comp. Physiol., 29, 99 (1948).

${ }^{2}$ Manery, J. F., Gourley, D. R. H., and Fisher, K. C., Canad. J. Biochem. and Physiol., 34, 893 (1956).

- Smillie, L. B., and Manery, J. F., Amer. J. Phyziol., 198, 67 (1960). ${ }^{\circ}$ Carey, M. J., and Conway, F. J., J. Physiol., 125, 232 (1954).

${ }^{10}$ Kernan, R. P., Nature, 185, 471 (1960).

1. Zierler, K. L., Science, 126, 1067 (1957).

\section{PHYSIOLOGY}

\section{Urocanicacidurea associated with Hepatic Coma}

WHILE studying the urinary chromatographic pattern of a patient in hepatic coma the presence of an abnormal spot $R_{F} 0 \cdot 14$ and 0.54 in propanol/ammonia, $7: 3$, and butanol/acetic acid/water, $4: 1: 5$, respectively, was noted after spraying paper chromatograms with diazotized $p$-sulphanilic acid. This colour reaction suggested that it might be an imidazole derivative, yet chromatography excluded the possibility of it being histamine, histidine or I-methylimidazole-4-acetic acid. (Table 1). As the presence of this unknown compound could not be related to the diet, or therapy, of the patient and appeared to be associated with the disease, an attempt was made to isolate it.

A 24-hr. urine sample was concentrated and acetone-precipitated according to the method of McIsaac and Page ${ }^{1}$. The final concentrate was streaked on Whatman No. 1 paper and chromatographed in butanol/acetic acid/water, $4: 1: 5$. The corresponding transverse strips of paper with $R_{F} 0.5-$ 0.6 were eluted with ethanol. The eluates were pooled and evaporated to dryness to yield $15 \mathrm{mgm}$. of crystalline material. Recrystallization from water yielded $10.6 \mathrm{mgm}$. of chromatogxaphically pure white crystals of urocanic acid (imidazole acrylic acid), m.p. $229^{\circ}$ C., mixed m.p. $228-29^{\circ}$ C., $\lambda_{\max } 277 \mathrm{m \mu}(p \mathrm{H} \quad 7 \cdot 4)^{2}$ (found: C, $40.9 ; \mathrm{H}, 5.9 ; \mathrm{N}, 16.0$ per cent ; 